Discussion Paper No. 13-021

\title{
Education and Lifetime Income During Demographic Transition
}

Friedhelm Pfeiffer and Karsten Reuß

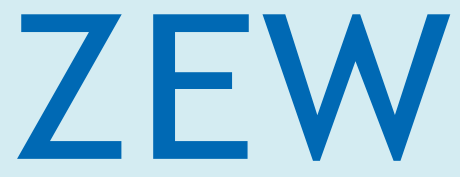

Zentrum für Europäische Wirtschaftsforschung $\mathrm{GmbH}$

Centre for European

Economic Research 
Discussion Paper No. 13-021

\title{
Education and Lifetime Income During Demographic Transition
}

\author{
Friedhelm Pfeiffer and Karsten Reuß
}

Download this ZEW Discussion Paper from our ftp server:

http://ftp.zew.de/pub/zew-docs/dp/dp13021.pdf

Die Discussion Papers dienen einer möglichst schnellen Verbreitung von neueren Forschungsarbeiten des ZEW. Die Beiträge liegen in alleiniger Verantwortung der Autoren und stellen nicht notwendigerweise die Meinung des ZEW dar.

Discussion Papers are intended to make results of ZEW research promptly available to other economists in order to encourage discussion and suggestions for revisions. The authors are solely responsible for the contents which do not necessarily represent the opinion of the ZEW. 


\section{Das Wichtigste in Kürze}

Die Studie untersucht den Zusammenhang zwischen Bildungsinvestitionen in verschiedenen Lebensphasen und der Nachhaltigkeit des umlagefinanzierten Rentenversicherungssystems in Deutschland. Kosten und Nutzen von Bildungsinvestitionen werden dabei mit Transferzahlungen verglichen, die direkt zur Reduktion von Ungleichheiten im Lebenseinkommen, insbesondere während des Rentenbezugs, beitragen. Die Studie vergleicht erstmals die Wirksamkeit von Bildungsinvestitionen für die Entwicklung der Lebenseinkommen unter Berücksichtung des demografischen Wandels. Dieser Vergleich wird für die Kohorten der in den Jahren 1940 bis 2044 Geborenen für die Zeitspanne von 2010 bis 2080 durchgeführt. Die Analyse basiert auf einem Modell der altersabhängigen Humankapitalbildung, das durch dynamische Komplementaritäten im Lebenszyklus gekennzeichnet ist.

Transferzahlungen werden mit kompensierenden Bildungsinvestitionen für unterschiedliche Altersgruppen verglichen, die beide das Potenzial haben, die Ungleichheit des Lebenseinkommens zu reduzieren. Dabei bietet unsere Analyse erstmals die Möglichkeit, auch die langfristigen Effekte von Bildungsinvestitionen abzuschätzen, die bereits in der frühen Kindheit getätigt werden. Die nachträgliche Korrektur der Lebenseinkommen durch Transferzahlungen während der Phase des Rentenbezugs und die vorsorgenden Bildungsinvestitionen haben jeweils spezifische Kosten und Nutzen für Kinder, Erwerbstätige und Rentner. Falls es das Ziel der Politik ist, die Ungleichheit des Lebenseinkommens innerhalb einer Generation zu verringern, sind aus Kosten-Nutzen-Überlegungen kompensierende Bildungsinvestitionen bis zum Alter von 17 Jahren, im Alter danach finanzielle Transferleistungen die bessere Wahl. Bildungsinvestitionen im Vorschulalter lassen aufgrund des Fähigkeitenmultiplikators der Kindheit die größten Erträge, gemessen am Lebenseinkommen, erwarten.

Prognosen zeigen, dass in den nächsten Jahrzehnten die Bevölkerung in Deutschland weiter altern wird. In Folge dessen wird der Anteil der Rentner an der Erwerbsbevölkerung im Erwartungswert von 30 Prozent heute auf 50 Prozent steigen. Zukünftige Rentensteigerungen werden trotz steigender Beiträge gering oder sogar negativ sein. Nach unseren Analysen könnten nach von im Jahre 2011 eingeführten steuerfinanzierten zusätzlichen Bildungsinvestitionen im Vorschulalter bereits die Geburtsjahrgänge ab 1976 in Form einer Zunahme ihres Lebenseinkommens profitieren. Bildungsinvestitionen im Vorschulalter können demnach bei gleichbleibendem Rentenrecht die ökonomischen Konsequenzen des demografischen Übergangs abmildern. 


\section{Non-technical summary}

The paper studies the power of educational investments in relation to transfers for fostering lifetime income and for reducing income inequality in Germany and contributes to the discussion of sustainability in the German public pension system in times of demographic transition in a novel way.

Costs and benefits of public transfer payments are examined that directly reduce income inequality at older age (called remedial policies) and compared with investments into education, beginning already at preschool age (called preventative policies). Furthermore, the paper studies the power of age-dependent educational investments for the development of lifetime income and inequality for cohorts born 1940 to 2044 over the period from 2010 to 2080 (intergenerational redistribution). The analysis is based on a model of age-dependent human capital accumulation, featuring dynamic complementarities in skill formation over the life cycle.

According to the findings educational investments are more effective in reducing income inequality than transfers in one generation until the age of 17 years. The relationship reverses after the age of 17. In case of remedial pension transfers in old age, the "rich" pensioner has to spend 100,000 € at the age of 65 years in order to increase the income of the "poor" pensioner so that the income inequality ratio is reduced moderately from 3.3 to 3.1 in Germany. To achieve the same reduction in inequality, the value of additional educational investments in preschool assessed at the age of 65 years is only $10,398 €$, demonstrating the power of the childhood skill multiplier.

Forecasts demonstrate that in the next decades the German population will decline as a consequence of declining fertily rates. Presumably, the old age dependency ratio will increase from 30 to over 50 percent, and the growth in average pensions will be moderate or even negative. According to our analysis tax-financed educational investments starting in 2011 could help to moderate the economic consequences of demographic transition.

The findings suggest that benefits will be positive on average, but not for all cohorts, mainly because of the significant lags between educational investments in childhood and increased human capital in adulthood. Cohorts born after 1976 will gain. The longer the planning horizon, the more positive the impact of educational investments on pensions in the German pension system will be. Investments into the youngest are the most productive. Additional educational investments into secondary education will presumably not raise lifetime income enough to compensate its costs. 


\title{
Education and Lifetime Income during Demographic Transition
}

\author{
Friedhelm Pfeiffer** and Karsten Reuß* \\ *ZEW Mannheim \\ ** ZEW Mannheim, University of Mannheim
}

April 8, 2013, comments welcome

\begin{abstract}
:
The paper studies the power of educational investments in relation to transfers for fostering lifetime income and for reducing income inequality in Germany. The welfare analysis is based on a model of age-dependent human capital accumulation, featuring dynamic complementarities in skill formation over the life cycle, and calibrated for the period of ongoing demographic transition until 2080. If policy aims at reducing the inequality of lifetime income among people of the same generation, educational investments for people younger than or equal to seventeen do a better job compared to transfers in adulthood. In an intergenerational perspective all cohorts born after 1976 will gain from tax-financed additional investments in preschooleducation introduced in 2011. Additional investments into secondary education will, as a rule, not cause life time income to raise enough to compensate its costs.
\end{abstract}

\section{Keywords:}

Early education, demographic change, inequality over the life span, redistributive policy

\section{JEL-classification:}

D63, H55, I20, J11

\section{Acknowledgements:}

We gratefully acknowledge support from the Leibniz Association, Bonn, through the grant "Noncognitive Skills: Acquisition and Economic Consequences". We would like to thank our colleagues for many helpful comments on an earlier version of this paper. The views expressed in this article are those of the authors and do not necessarily reflect the views of the Leibniz Association. The usual disclaimer applies.

\section{Corresponding author:}

Karsten Reuß, Centre for European Economic Research (ZEW), P.O. Box 103443, D-68034

Mannheim. Phone: +49-621-1235-287, E-mail: reuss@zew.de 


\section{Introduction}

The paper analyses the power of investments into education in relation to transfers for the evolution of lifetime income and income inequality in Germany. A model of human capital accumulation across the life span is developed and calibrated taking into account age-dependent skill formation and the expected demographic transition during the century (until 2080). If policy aims at reducing the inequality of lifetime income among people of the same generation, either investment into education for people younger than or equal to seventeen or transfer payments for people older than eighteen years are needed. Incorporating demographic transition in the next decades in Germany, the findings demonstrate that cohorts born after 1976 will gain from tax-financed additional investments in preschool-education introduced in 2011. Additional investments into secondary education will not cause life time income to raise enough to compensate its costs.

In Germany, the inequality of public pensions is determined to a significant degree by income inequality during the working life (see Börsch-Supan and Ludwig, 2009, among others). As wage inequality is increasing (see Dustman et al. 2009, Gernandt and Pfeiffer 2007, among others), inequality in public pensions might also increase in future generations of pensioners. Since income differentials significantly depend on investments into education (see Cunha and Heckman 2008a, Gebel and Pfeiffer 2010, among others), long-run policies to reduce inequality in lifetime income should concentrate on investment into education, while transfer payments are capable of reducing inequalities at older age.

In our analyses the term "investment into education" is used to cover all measures that are able to improve skills, regardless of whether they take place in the family, by friends or through teaching. The optimal timing and the optimal quantity of investments into people have recently been discussed in the economic literature. Since deep-seated skills are created early in the human developmental process (Armor 2003, Blomeyer et al., 2009, 2013, Heckhausen and Heckhausen 2008, Heckman 2007, among others) the priorities in public educational spending are under scrutiny. The formation of cognitive skills, such as intelligence, memory power and reasoning, and self-regulatory skills, such as motivation, delay of gratification and persistence, begins in early childhood, influenced by parent-child interaction. The level of these skills seems to be decisive for becoming a productive member of society and for economic performance as well (Cunha and Heckman 2009, Hanushek and Wössmann 2008, among others).

To the best of our knowledge this paper and its predecessor (Pfeiffer and Reuß 2008b) provide the first comprehensive assessment of age-dependent investments into education and its implications for lifetime income and reducing income inequali- 
ty during a century of demographic transition in Germany. The paper contributes to the discussion of the long-run development of the German public pension system in times of demographic transition (compare Börsch-Supan and Ludwig, 2009, and Vogel et al., 2013, among others) in a novel way. First two policies to reduce the inequality of lifetime earnings are analysed. Costs and benefits of public transfer payments are examined that directly reduce income inequality at older age (called remedial policies) and compared with investments into education, beginning already at preschool age (called preventative policies). Second, the paper studies the power of age-dependent educational investments for the development of lifetime income and inequality for cohorts born 1940 to 2044 over the period from 2010 to 2080 (intergenerational redistribution).

Findings can be summarised as follows. Both compensating measures for reducing the inequality of lifetime incomes have their specific costs and benefits for the generation of the children, the working population and the pensioners. If the policy goal is to reduce the inequality of lifetime earnings among people of the same generation, either investment into education for people younger than or equal to seventeen or transfer payments for people older than eighteen years are needed. Especially compensating preschool-age investments have the power to reduce the inequality in lifetime earnings due to the childhood skill multiplier in the longer run. Incorporating the demographic transition in the next decades in Germany, findings demonstrate that cohorts born after 1976 would gain from tax-financed additional investments in preschool-education introduced in 2011. Additional educational investments into secondary education will presumably not cause future lifetime income enough to compensate its costs.

The paper is organised as follows. Section 2 introduces the basic analytical tool for examining human capital formation and its application to study the evolution of lifetime income and income inequality in Germany, taking into account the federal German public pension system and the on-going demographic transition until 2080. Section 3 discusses the findings from the comparison of preventative and remedial policies to reduce the lifetime income inequality within a generation (intragenerational redistribution). Section 4 investigates the evolution of lifetime income and inequality for the cohorts of people born 1940 to 2044 over the period from 2010 to 2080 (intergenerational redistribution). Section 5 concludes.

\section{Modelling Lifetime Income in Germany}

Human skills that generate income are multidimensional. Cognitive skills comprise memory power, information processing speed, intellectual power, linguistic skills as well as general problem solving abilities. Yet, cognitive skills alone are insufficient for devising purposes and for regulating the self. Skills relevant for those tasks are subsumed by the term "non-cognitive skills" in the economic literature (Heckman 
2007), such as persistence, time and risk preferences or self-discipline (Borghans et al. 2008, Coneus et al. 2012, among others). Non-cognitive skills seem to be as important as or even more important than cognitive skills with respect to human capital formation (Duckworth and Seligman 2005, Cunha and Heckman, 2007, among others).

The returns on investment into education seem to depend on the stage in the life cycle in which the investment was made. In particular, early childhood seems to be a critical period for skill formation. Early investments will be productive for a longer time as skill and competency formation is a cumulative process. In addition, and even more importantly, competencies early acquired may facilitate further human capital formation as a result of dynamic complementarities (see Beckett et al. 2006, Blomeyer et al., 2013, Cunha et al., 2006, Heckman 2007, among others). Research suggests that 40 percent to one half of the persistence of intergenerational income inequality can be explained by the family's investment into education during the early life cycle (Pfeiffer and Reuss, 2008a, Restuccia and Urrutia 2004).

In order to model age-dependent features of skill formation Pfeiffer and Reuss (2008a) introduce two learning multipliers determining the persons' learning aptitude, one for cognitive, $\mathrm{l}_{\mathrm{t}}^{\mathrm{C}}$, and one for non-cognitive skills, $\mathrm{l}_{\mathrm{t}}^{\mathrm{N}}$, respectively, see Figure 1 (top). The model is inspired by the technology of skill formation by Cunha and Heckman (2007). Skill formation is viewed as a synergetic process which is characterised by the properties of self-productivity (a high level of skills begets further competency formation) and direct complementarity (the differential return on additional investments in education increases with the stock of already acquired skills).

There are two equations, one for cognitive, $S_{t}^{C}$, and one for self-regulatory skills, $S_{t}^{N}$, that specify skill formation and depreciation for every individual over the life span on a yearly basis. The basic structure of the equation for the development of skill $k$ of individual $n$ in period $t$ is:

$S_{t, n}^{k}=\psi^{k} \cdot l_{t}^{k} \cdot\left\{1 / 3\left(S_{t-1, n}^{k}\right)^{\alpha}+1 / 3\left(S_{t-1, n}^{j}\right)^{\alpha}+1 / 3\left(I_{t, n}^{k}\right)^{\alpha}\right\}^{-\alpha}+\left(1-\delta_{t-1}\right) \cdot S_{t-1, n}^{k}$

with $\delta_{t}=[a s \cdot(L e+1-t)]^{-1} k=C, N$ and $\mathrm{j}=C$ if $k=N, j=N$ if $k=C$ and $S_{t, i, j}^{k} \geq 0$.

The first term represents skill formation as a CES production function and the second the stock of previous period's skills minus depreciation, $\delta_{t-1}$. Next period skills are produced by the level of both skills and by investments, $I_{t, n}^{k}$. Thereby the learning multipliers are involved as well as $\psi^{k}$, which is an adjustment factor for the units to measure skills. $\alpha$ is the degree of complementarity among skills and investment. Each factor in the skill production function is assumed to add to the new skills with the weight of $1 / 3$. This assumption produces a similar degree of self-productivity 
measured by Cunha and Heckman (2008b). Depreciation of skills $\delta_{t}$ is modest in childhood and accelerates with increasing age; life expectancy $L e$ is assumed to be 80 years. In their last period of life individuals lose all their skills (and die).

Figure 1 (bottom) illustrates the resulting level of cognitive and self-regulatory skills over the life cycle for a "standard" individual. A standard individual represents the $50^{\text {th }}$ percentile of skill and income distributions and is characterised by a constant annual flow of one educational investment. The amount of investments results from the family and scholl environment. Different levels of investments lead to a population of individuals whose skills will become more and more heterogeneous in the course of life. Further variations in the initial endowments at birth are investigated in Pfeiffer and Reuss (2008a).

Human capital in the model is assumed to be produced by the cognitive and non cognitive skills which are assumed to create income in labour markets. Thus, the stock of human capital is a function of cognitive and non cognitive skills and it is subject to depreciation:

$$
H_{t, n}=\sqrt{S_{t, n}^{C} \cdot S_{t, n}^{N}}+\left(1-\delta_{t}^{H}\right) H_{t-1, n}
$$

Human capital depreciates according to $\delta_{t}^{H}=\psi_{H} \cdot \delta_{t}$, where $\psi_{H}$ is a parameter which may vary between individuals, jobs, industry or over time. A high value of $\psi_{H}$ will lead to an early human capital maximum (like in sports), a small $\psi_{H}$ to a later maximum (like in science). An age of around 52 years is chosen as the human capital maximum and $\delta_{t}^{H}$ is adjusted accordingly.

Let $\theta_{t, n}$ be the fraction of working time per year. Then gross labour income, GLI, are calculated for each individual $n$ from the level of human capital and the distribution of labour income. This distribution depends not only on the distribution of skills among the labour force but also on labour market features, e.g. on the degree of centralisation in wage negotiation or the regulation of employment. It is asumed that labour markets with a more unequal wage distribution show larger income than human capital variation. The opposite is true for labour markets with a more uniform wage distribution (Pfeiffer and Reuß 2011).

$$
G L I_{t, n}=\theta_{t, n} \cdot \psi_{H} \cdot H_{t, n}^{\gamma_{H}} \cdot H_{t, \text { median }}{ }^{-\gamma_{H}} \cdot H_{t, \text { median }}
$$

The parameter $\gamma_{\mathrm{H}}$ is used to adjust the wage inequality to different labour markets. Values of $\gamma_{\mathrm{H}}$ larger than one strengthen the skill heterogeneity while values smaller than one reduce income inequality. In Germany, average annual gross labour income in the industrial sector amounts to 41,468 € (Federal Statistical Office Germany 2010a). The resulting lifetime (labour) income amounts to about 1.4 million $€$ for an 
individual with average skills working from period 18 till 65. $\psi_{H}$ is adjusted in Equation (4) to fulfil this condition. Subsequent to working life people retire and receive pension payments. According to the pension formula (Deutsches Institut für Altersvorsorge 2011), the monthly amount of pension payment ("Rentenzahlbetrag", $R Z B$, in terms of the German legislation) is calculated from the number of personal income points ("Entgeltpunkten", EP) acquired during working life, the access factor in pension calculation ("Zugangsfaktor", $Z u$ ), the pension type factor (“Rentenartfaktor”, $R$ ) and the pension value (“aktueller Rentenwert”, $a R W$ ):

$$
R Z B=E P * Z u * R * a R W
$$

For simplification, it is assumed that there are only old-age pensions due to employment. Thus, $Z u=R=1$. The number of personal income points which are acquired in each year of working life are calculated from gross labour income of individual $n$ in period $t, G L E_{t, n}$, the contributions assessment ceiling ("Beitragsbemessungsgrenze", $B B G_{t}=63.929 €$ ) and the average labour income according to the following formula:

$$
E P_{n}=\sum_{t}^{T} \min \left\{G L I_{t, n} ; B B G_{t}\right\} \cdot G L I_{t, \text { average }}^{-1}
$$

In modelling intragenerational redistribution the pension value is determined such that it implies the average pension of 14,352 $€$ (average value for East and West Germany) per annum in 2010, which corresponds to the pension payment for longtime insured persons in Germany (German Federal Pension Insurance 2011). The pension value is given by $26.58 €$ for 2010 and will be updated until 2080 according to demographic transition and wage growth.

\section{Intragenerational Redistribution}

\subsection{Framework}

In order to investigate intragenerational redistribution one cohort of individuals is considered over the whole life cycle in a stationary world. Individuals differ with respect to the amount of investment in their skills that they receive from their family and school environment. Three types of individuals are distinguished: low-skilled, medium-skilled and high-skilled. For simplicity, each type consists of one individual only. The low-skilled person $(n=1)$ receives enough investment in education to exactly reach the $10^{\text {th }}$ percentile (or alternatively the $1^{\text {st }}, 20^{\text {th }}$ or $40^{\text {th }}$ ) of the distribution of labour income, whereas the high-skilled person $(n=2)$ reaches the $90^{\text {th }}$ percentile (or alternatively the $99^{\text {th }}, 80^{\text {th }}$ or $60^{\text {th }}$ ). The medium-skilled person corresponds to the standard individual representing the median of the income distribution. For reasons of simplicity, the medium skilled individual is ignored when analysing intragenerational redistribution. Life expectancy, $L e$, is assumed to be fixed at 80 years in this 
section (Section 4 will introduce a more dynamic life expectancy pattern with mortality rates).

The model allows redistribution to have feedback effects on the investments in education during working life as individuals maximise their discounted lifetime earnings - as it is shown below. The German Statutory Pension Insurance system (see German Federal Pension Insurance 2009, Pfeiffer and Reuß 2011)) is modelled for a generation of two individuals as follows: In each period of working life, the pension insurance contribution of an individual is defined by the fraction $\tau$ of one's gross labour income, $G L I_{t, n}$. By assumption, two percent interests are paid on the payments. The amount of pension payments is determined by the balanced budget condition of the pension system, i.e. aggregate pension payments, Pension $_{t}$, are defrayed by the sum of contributions. The level of old-age pensions is determined by the contribution rate $\tau$ during working life. $\tau$ is chosen to fit the standard individual's pension, which is set equal to $14,352 €$, the actual level of the average annual old-age pension for Germany.

The balanced budget condition is given by:

$$
\sum_{n=1}^{2} \sum_{t=66}^{80} \text { Pension }_{t, n}=\sum_{n=1}^{2} \sum_{t=18}^{65} \tau \cdot G L I_{t, n}
$$

Individual pension receipts are based on the accumulated personal earnings points:

$$
E P_{t, n}=G L I_{t, n} \cdot\left[\sum_{n=1}^{2} G L I_{t, n} / 2\right]^{-1}
$$

The individual fraction of pension payments is calculated according to the following formula:

$$
v_{n}=\left(\sum_{t=18}^{65} E P_{t, n}\right)^{\gamma_{R}} \cdot\left(\sum_{n=1}^{2} \sum_{t=18}^{65} E P_{t, n}\right)^{-\gamma_{R}} / \sum_{n=1}^{2}\left[\left(\sum_{t=18}^{65} E P_{t, n}\right)^{\gamma_{R}}\left(\sum_{n=1}^{2} \sum_{t=18}^{65} E P_{t, n}\right)^{-\gamma_{R}}\right]
$$

The parameter $0<\gamma_{R}<1$ governs pension policy. If $\gamma_{R}=1$, there is no redistribution and the equivalence principle is valid. For $\gamma_{R}=0$ both individuals receive the same amount of pension payment, which is the strongest outrage against the equivalence principle possible. For simplicity neither a social system nor a social safety net in old age are assumed. Over the life cycle the individual's net incomes are composed of net labour incomes and pensions: 


$$
\text { NetInc }_{n, t}=\left\{\begin{array}{cc}
(1-\tau) \cdot G L I_{n, t} & \forall 18 \leq t \leq 65 \\
v_{n} \cdot\left(\sum_{n=1}^{2} \sum_{t=66}^{80} \text { Pension }_{t, n}\right) / 15 & \forall 66 \leq t \leq 80
\end{array}\right.
$$

Figure 2 illustrates the course of gross and net income for high and low-skilled people over the life cycle. Income inequality increases with age.

Individuals choose the amount of annual, adult investments in education, $I_{18.80}^{*}$, so that the sum of their discounted net income is maximised. Uncertainty of returns to educational investment is ignored (see Krebs 2003). In choosing the optimal amount of investment, each individual bears the decision of the other in mind, because the investment decisions influence each other. This interdependency follows both from wage setting and the extent of labour market inequality as well as the division of pension payments. Consequently, feedback and incentive effects of redistribution aimed to reduce inequality are taken into account by the model.

$$
I_{t, n}^{C, N^{*}}=\arg \max \left[\sum_{t=18}^{80}\left(\operatorname{NetInc}_{n, t}\left(I_{t, n}^{C, N^{*}}, I_{t, n \neq m}^{C, N^{*}}\right)-I_{t, n}^{C, N^{*}}\right) \cdot \operatorname{Cost}_{t, n} \cdot(1+r)^{-(t-18)}\right]
$$

Each investment unit in education of adults costs $\operatorname{cost}_{t, n}=11,478 €$ annually. This value equals the OECD (2010) calculation for per capita expenditures of tertiary education in Germany (conversion based on the PPP according to OECD.stat 2011 was conducted). The optimal investment in adult life shows a steadily declining course (Figure 3). High-skilled people invest much more than low-skilled people during their working life. This difference results from the cumulative nature of skill formation and demonstrates the complementarity of investments in education over the life cycle. Additional investments in education are more profitable to someone who starts working life with more skills and a higher level of human capital.

\subsection{Measures to reduce inequality over the life cycle}

In the following, three possible measures to reduce the inequality of lifetime earnings between both individuals are compared. All measures have in common that there are no additional resources provided exogenously. The high-skilled individuals rather have to convey some of their resources to the low-skilled. This can happen at different stages during the life cycle. We consider possible costs of such transfers inasmuch as they affect the investment decisions during the working life. To measure income inequality the ratio of lifetime earnings of high-skilled ( $90^{\text {th }}$ percentile) and low- skilled ( $10^{\text {th }}$ percentile) is utilised. As initial condition - i.e. before redistribution is implemented - the earnings ratio is adjusted to 3.3, which roughly is the inequality of gross hourly wages in Germany (OECD.stat 2011, Gernandt and Pfeiffer 2007). 
Interventions having a cumulated discounted value of $20000 €$ in period 65 are computed for redistributions between two individuals, either the $60^{\text {th }}$ and $40^{\text {th }}, 80^{\text {th }}$ and $20^{\text {th }}, 90^{\text {th }}$ and $10^{\text {th }}$ or the $1^{\text {st }}$ and $99^{\text {th }}$ percentile of the income distribution. One unit of primary education is assumed to cost 6,011.92 $€$ annually, which equals the average education expenditure in Germany (OECD 2010) (conversion based on the PPP according to OECD.stat 2011 was conducted). The flows of resources are always discounted to the age of 65 in order to guarantee comparability. The interest rate used for discounting is set to two percent.

As a first measure the redistribution of pensions is examined. In the period of pension receipt high- skilled individuals have to conduct remedial transfers to the lowskilled. The second measure is a redistribution of preventative investments in education that are done before entering the labour force. During childhood the low-skilled individual receives as much resources for investment that lifetime earnings inequality is reduced to a target value. The high skilled has to transfer this money from their educational investment budget. The third measure which is called "pension financed investment in education", analyses the effects of preventative investments in education during childhood, too. But in contrast to the second measure, investments in education are not taken out of the high-skilled people's educational budget but are financed by a credit, which the high-skilled have to repay during the period of pension receipt. The model assumes a frictionless capital market that enables such transactions without costs.

The results of the comparative analysis are presented in Table 1 . It comprises average investments in education during working life, lifetime net inomce, the sum of pension payments and the total lifetime income of the analysed generation for each of the four variables initial situation, redistribution of pensions, redistribution of investments in education, and pension financed investment in education. Redistribution of pensions (see Table 1, row (a)) reduces the incentives for educational investment of both individuals. The reduction is larger for the high-skilled person as the redistribution of pensions lowers the return on her investment in education compared with the initial situation. The reduction of investments leads to a decline of lifetime earnings and thus the reduction of inequality by redistribution of pensions lessens social income between -0.14 and 0 percent. For the redistribution between the $99^{\text {th }}$ and the $1^{\text {st }}$ percentile the loss is marginal.

In contrast, a redistribution of investments in education (see Table 1, row (b)) can lead to an increase or a decrease in the sum of incomes depending on the percentiles. Changes in the sum of incomes vary from -0.06 percent to +1.7 percent. The sum of endogenous investments in education during working life is slightly smaller if investments among types are redistributed. This leads to a decrease of overall income in case of redistribution between the $60^{\text {th }}$ and the $40^{\text {th }}$ percentile. For distributions between the other percentiles this is not the case. The skill production function is 
characterised by decreasing marginal rates of return. Thus an increase in investments is more productive for the low-skilled the higher the relative difference is between the high- and the low- skilled. Due to dynamic complementarities, the additional investments in education of the low- skilled induces more investment during adult age and similarly the loss of educational investments during childhood leads the highskilled to invest less during working life. As a result, a marginal redistribution of investments in education during early childhood not only reduces inequality, but also increases total income the higher the difference between the percentiles is.

In comparison, pension-financed investment in education (see Table 1, rows (c)) does not reduce the educational attainment of the high-skilled during childhood. Early investments induce the low-skilled person to increase her investments in human capital also at adult age. The two channels combined let total income grow between 2.9 and 4.16 percent. To sum up, the pension financed investment into education seems to be the most effective measure to reduce inequality.

\subsection{Welfare analysis of intragenerational redistribution}

If inequality aversion becomes important total income no longer is an appropriate measure to evaluate policies. An alternative measure is the social welfare function developed by Sen et al. (1997), and Atkinson (Atkinson 1970). The Atkinson Index is a discrete measure of inequality for an income distribution of a population with $\mathrm{N}$ individuals:

$$
A_{\varepsilon}=1-\left[1 / N \sum_{n=1}^{N}\left(\operatorname{NetInc}_{n} / \mu\right)^{1-\varepsilon}\right]^{\varepsilon-1} .
$$

$\mathrm{NetInc}_{n}$ terms individual net income accumulated over the life span, $\mu$ the average income of the population. $\varepsilon$ is a parameter for indicating different degrees of equality preferences in the society. For $\varepsilon=0$ a society does not care about equaliy at all. For $\varepsilon=\infty$ the index depends only on the welfare of the poorest individual of the society. The Atkinson Index is normalised between 0 and 1 . If $A_{\varepsilon}=0$ no inequality is considered in the distribution while inequality is at its maximum if $A_{\varepsilon}=1$. In social reality equity considerations vary from $0.5 \leq \varepsilon \leq 2.5$. Based on this index the following Sen Welfare function for the population is utilised:

$$
W(Y)=\left(1-A_{\varepsilon}\right) \cdot \sum_{i=1}^{N} \operatorname{NetInc}_{n}
$$

Figure 4 shows the percentage change of the welfare functions for the three polcies relative to the initial state. The analysis is conducted for several different inequality aversions $\varepsilon=0.1, \varepsilon=0.8, \varepsilon=2.5$ and $\varepsilon=10$. For $\varepsilon=0.1$ the welfare changes are similar to the total income changes. For higher $\varepsilon$ the effect of the social welfare function at the edge of the distribution is basically equal, because redistribution of invest- 
ments in education (b) results in a greater inequality reduction relative to pensionfinanced investment in education (c) even though the gain in total total income is smaller. All in all, redistribution of investments in education (b) in no case is paretodominant to pension-financed investment in education (c).

The analysis demonstrates that the best results in reducing the inequality of lifetime income can be achieved by an increase of preventative investments in education during childhood for low-skilled individuals without reducing investments in education for the high-skilled. One may argue that the the hypothetic world studied does not include uncertainty and therefore its validity is limited. However, the introduction of uncertainty with respect to the period of pension payment will strengthen the above statement because redistribution of pensions will last only a shorter time of the life cycle. All in all, precautionary measures that reduce inequality tend to be cheaper than remedial corrections from an economic point of view. Moreover, precautionary measures increase total income so that the losers of redistribution, i.e. the highskilled, can theoretically be compensated.

\subsection{Cost analysis}

Finally, the age-dependent costs for each measure that reduces lifetime inequality are analysed. As an illustration, the existence of exogenous financial resources for these redistribution measures is assumed. In the case of redistribution of pensions the lowskilled individual of the $10^{\text {th }}$ percentile has to receive $100,000 €$ at the age of 65 years in terms of remedial transfers in order to reduce the 90-10 lifetime earnings inequality ratio from 3.3 to 3.1 .

This amount can alternatively be compared with preventative investments in education at different ages that the low- skilled receives. For each stage of life, the amount of investment necessary to reach the inequality goal is determined. This results in an investment of 2,939 $€$ in preschool age ( 0 - 5 years old) which corresponds to a capital value of $10,398 €$ at the age of 65 years - only a fraction of those 100,000 $€$ stemming from the childhood skill multiplier and dynmic complementarities. The costs increase in age as the multiplier becomes smaller. According to the model, investment costs in education at age 17 reach the costs of the pension transfer and surmount them in later years, see Figure 5. To sum up, premedial investments in education should be preferred to redistribution of pensions through direct transfers until the age of 17 years in order to reduce earnings inequality. Transfer payment are more efficient at older ages. 


\section{Intergenerational redistribution}

\subsection{Modelling demographic transition}

This section analyses the consequences of investments in education which are financed by an additional tax introduced in 2011 with respect to the development of public pensions in an intergenerational dimension. These additional investments in education will increase the human capital of the young generation, their labour income and their pensions. As investments in education affect productivity with considerable time lags, not all cohorts of employees will gain from the expected rise in pensions to the same extent. The model is used to assess which generations profit from additional, tax-financed investments in education. For reasons of simplicity, the impact of private savings on the level of lifetime earnings is ignored. For the discussion of pay-as-you-go schemes versus funded systems compare Börsch-Supan and Ludwig (2009), among others.

The foundation for modelling the demographic part is the $12^{\text {th }}$ coordinated population projection by the Federal Statistical Office (2009a). The analysis covers the time span $t=2010$ to $t=2080$ and all age-groups between $z=1900$ and $z=2080$. As initial condition the composition of the population projected for the year 2010 is chosen with respect to generation and gender taken from Pfeiffer and Reuß (2008b). It is updated according to two differential equations, one for men $M_{t, z}$ (14) and one for women $W_{t, z}(15)$ :

$$
\begin{aligned}
& M_{t+1, z}=M_{t, z}+\operatorname{Immi}_{t, z}^{M}-\left(p_{t, z}^{d, M}+p_{t, z}^{e, M}\right) \cdot M_{t, z} \\
& W_{t+1, z}=W_{t, z}+\operatorname{Immi}_{t, z}^{W}-\left(p_{t, z}^{d, W}+p_{t, z}^{e, W}\right) \cdot W_{t, z}
\end{aligned}
$$

Here $\operatorname{Immi}_{t, z}^{M, W}$ stands for immigration of people of generation $z$ and gender $M$ or $W$ in period $t$. $p_{t, z}^{d, M}, p_{t, z}^{d, W}, p_{t, z}^{e, M}$ and $p_{t, z}^{e, W}$ represent the mortality rate and the probability of emigration, respectively. The mortality rates for each cohort are taken from statistics of the Federal Statistical Office (2011). Mortality rates are generally smaller for women than for men of the same age. They are likely to decline further (e.g. as a result of medical progress) so that life expectancy will increase. The model is calibrated such that the life expectancy of the total population at birth will increase from 82.5 years for women and 77.3 years for men in 2009 to 86.4 years for men and 90.3 years for women in 2060. These values lie between the values of two different scenarios in the $12^{\text {th }}$ coordinated population projection for 2060 (89.2 years and 91.2 years for women; 85 years and 87.7 years for men). The increase in lifetime expectancy is expected to occur steadily. 
The distribution of immigrants with respect to age is taken from the statistics of migration (Federal Statistical Office Germany 2009b). Immigration in 2009 amounted to 721,014 people over all age-groups while younger ages and men aged between 20 and 30 years were represented above average. These fractions among immigrants are assumed to stay constant. About 733,796 persons emigrated from Germany in 2009. The probabilities of emigration are updated depending on age and gender - different from immigration values. Thus, as the population decreases, emigration may also decrease in total numbers. The development of the population is furthermore determined by fertility rates. According to the Federal Statistical Office Germany (2010b), an average German woman gave birth to 1.38 children in 2008. The model employs the age-dependent fertility rates, $p_{t-z}^{g}$, from 2008 to forecast the number of newborns summed over all female cohorts:

$$
\text { Newborns }_{t}=\sum_{z=1900}^{t} p_{t-z}^{g} \cdot W_{t, z}
$$

With respect to gender allocation, it is assumed that 95 newborn girls are born per 100 newborn boys (Federal Statistical Office Germany. 2009a). As the number of births per woman has been relatively stable for the last 20 years, varying from 1.28 in 1993 to 1.45 in 1990, they are assumed to remain constant.

With these assumptions, the German population will decline to about 72 million in 2050 (Figure 6). This value lies in the middle of the spectrum (between 67 and 75 million) of the different variants in $12^{\text {th }}$ coordinated population projection (Federal Statistical Office Germany 2009a). The number of nwborns will decrease from 673,000 in 2010 to 510,000 in 2050 . The old-age dependency ratio ${ }^{1}$ will increase to 52 percent due to the higher life expectancy and the retiring baby boomer generations born between 1955 and 1964. Note that the rise in statutory retirement age to 67 years as decided by legislation has been taken into accouint. Figure 7 shows the onetime effect of this rise in retirement age on the old-age dependency ratio. Both drops in 2012 and 2023 are caused by a rise of retirement age that is implemented in only two steps for simplification. The results indicate that the moderate increase in retirement age will not reduce the old-age dependency ratio during demografic transition, which is in line with Börsch-Supan et al. (2008).

\subsection{Modelling income and the pension system}

Equation 4 determines the development of gross labour income of 2010 over the life cycle in alternative cases of age-dependent investments in education. This equation is the basis for modelling the relationship between income and pension payments in the German Statutory Pension Insurance system. Calibration of $\gamma_{\mathrm{H}}$ and $\psi_{\mathrm{H}}$ to the average income and income inequality is conducted similarly to Pfeiffer and Reuss

\footnotetext{
${ }^{1}$ Ratio of people above 65 years to the number of people of working age (18 to 65 years), see Equation 19.
} 
(2008b). Gross labour income of an employee subject to compulsory insurance, of cohort $j$ and qualification group $i$ in period $t$ are:

$$
\text { GrossIncome }_{t, z, n}=\varphi_{\mathrm{Ec}}^{(t-2010)} \cdot G L I_{t-z, n} \quad \forall t-\text { rea }_{t}<z \leq t-18
$$

As described in Section 2, people earn income in the labour market from the age of 18 on, until the retirement age rea ${ }_{t}$ (at first 65, later 67 years). The parameter $\varphi_{E c}^{(t-2010)}$ introduces exogenous economic growth which is assumed to be one percent per annum. Five individuals in the economy represent the $10^{\text {th }}, 30^{\text {th }}, 50^{\text {th }}, 70^{\text {th }}$, and $90^{\text {th }}$ percentile of the income distribution. There are no gender differences with respect to the human capital development over the life cycle. Let $\theta^{E}$ be the fraction of employees in the total population which is set to 75 percent (Commission of the German government for achieving financial sustainability for the social security systems 2003). Total income obtained in one year is the sum of the individual gross labour income (Equation 18) and the average employee's income average over the employed population:

$$
Y_{t}=\sum_{z=1900}^{t} \sum_{n=1}^{5}\left(\text { Grossincomes }_{t, z, n} \cdot \theta^{E} \cdot M_{t, z}+W_{t, z} / 5\right)
$$

The ratio between pension recipients and employed contributors, the old-age dependency ratio, $D R$, is given by Equation 19:

$$
D R_{t}=\sum_{z=1900}^{t-R e a_{t}}\left(M_{t, z}+W_{t, z}\right) \cdot\left[\sum_{z=t-R e a_{t}}^{t-18} \theta^{E} \cdot\left(M_{t, z}+W_{t, z}\right)\right]^{-1}
$$

By means of the pension calculation formula the net total income and pension payments are calculated by Equation 20. They include the sum of income points and the pension value, $a R W_{2010}$ (see Equation 22). For an individual $n$ of cohort $z$ at time $t$ the monthly amount of pension payment, $R Z B_{t, z, n}$, follows:

$$
R Z B_{t, z, n}=E P_{z, n} * Z u * R * a R W_{t}
$$

As in Section 3, it is assumed that there are only statutory old-age pensions due to employment $(Z u=R=1)$. In the German pay-as-you-go system the sum of personal income points $E P_{z, n}$ is calculated from gross labour income of individual $n$ in each year of working life $t$, GrossIncomes ${ }_{t, n}$, the contributions assessment ceiling ("Beitragsbemessungsgrenze”, $\left.B B G_{t}=63.929 €\right)$ and the average labour earnings, $\varnothing_{t}$, according to the following formula:

$$
E P_{z, n}=\sum_{t=z+18}^{2+\text { Rea }}\left(\min \left\{\text { GrossIncomes }_{t, z, n} ; B B G_{t}\right\} / \varnothing_{t}\right)
$$


The pension value, $a R W_{2010}$, in 2010/11 in Germany is $26.58 €$ (German Federal Pension Insurance 2011). It is calculated according to the following formula:

$$
a R W_{t}=a R W_{t-1} * \frac{\varnothing_{t-1}}{\varnothing_{t-2}} * \frac{100-A V A-\tau_{t-1}}{100-A V A-\tau_{t-2}} *\left[\left(1-\frac{D R_{t-1}}{D R_{t-2}}\right) * \alpha+1\right]
$$

The weighting parameter $\alpha$ stabilises the replacement rate for a value of 0 and the contribution rate for a value of 1 (see also Krüger and Kübler 2002). Its value is set to 0.25 by law ( $\S 68$ Absatz 4 Satz 6 SGB VI) in order to avoid an increase of the contribution rate to more than 22 percent by 2030 . The contribution rate and pension payments depend on each other. A higher contribution rate increases pension payments and vice versa. The proportion of old-age provision factor ("Altersvorsorgeanteil”) for 2010 in Germany is assumed to be 4, which is the defined value for 2012 (§ 255e SGB VI). Thus, the annual, individual pension entitlement is given by:

$$
\text { Pension }_{t, z, n}=a R W_{t} \cdot E P_{z, n} \cdot 12 \quad \forall z \leq t-\text { rea }_{t}
$$

As a consequence, the annual total pension payments $T P P_{t}$ of the German Pension insurance for the population of 5 types of individuals are:

$T P P_{t}=\theta^{E} \cdot \sum_{z=1900}^{t-R e a_{t}} \sum_{n=1}^{5}\left(M_{t, z}+W_{t, z}\right) / 5 \cdot$ Pension $_{t, z, n}$

In 2010 the contribution rate to the pension insurance is 19.9 percent $\left(\tau_{2010}=19,9\right)$. In the study the contribution rate is adjusted according to the pension entitlements on the basis of earning points:

$\tau_{t}=\frac{T P P_{t}}{Y_{t}}$

\subsection{Measures for intergenerational redistribution}

To model intergenerational redistribution, an income tax $\xi$ is introduced, which all employees have to pay. The tax amounts to one percent of gross income. It is assumed that policy starts in the year 2011. The tax revenues are invested into children in two different age-groups ( 0 to 6 years or alternatively 12 to 18 years). One unit of educational investment in the model costs 6,011.92 $€$ per year (this corresponds to the average expenditures for education in the primary school in Germany, OECD 2010). By assumption, these additional investments become effective to the full extent by the formation of skills and human capital in accordance with Equation 1. Crowding out of private or public investments is assumed to be absent. Investments will increase labour income and pensions in the later life. The net income of individual $n$ of cohort $z$ at the time $t$ is given as: 
NetIncomes $_{t, z, n}=\left(1-\tau_{t}-\xi\right) \cdot$ GrossIncomes $_{t, z, n}+$ Pension $_{t, z, n}$

For the results in Figure 8, a world without an exogenous technological progress is assumed. That way the impact of demographic change on the pension system can be isolated. Figure 8 (top left) compares an individual born in 2011, who received a support for the first six years of life, with one who received no additional support. The figure illustrates that the return on this investment in terms of a higher income develops with a delay of eighteen years and continues to increase with age (the gap between the two alternatives becoming greater). It peaks approximately in 2060 . Figure 8 (top right) shows the per capita labour incomes with and without the policy. Even without the additional educational investments, earnings slowly increase until the year 2025 due to the increase in the average age of employees. Subsequently, the baby boomers will retire causing the average labour income to reduce slowly. The policy, however, can prevent the reduction and make average labour income continue to rise beyond the year 2050. After 2050 the positive impacts of the human capital increase will unfold entirely.

From the year 2040 on the pension value will decrease from above $26 €$ to $22 €$, if the pension calculation formula remains unchanged (Figure 8, bottom left). A simultaneous increase in the contribution rate will be experienced. After 2040 the pension value stabilises on a low level. The policy impact will mainly come out only in 2040, so that the reduction of pensions cannot be stopped. From 2040 on, however, the pension value will be significantly higher with the policy. As Figure 8 also shows (bottom right), the decrease of the contribution rate is only marginal. Due to the fact that the contribution rate increases only marginally with pensions increasing significantly, it could be possible that some cohorts have a preference for this policy, which is analysed in greater detail in Section 4.

Alternatively, 12 and 17 year-olds receive the additional educational investments. If the policy starts in 2011, benefits will already come out by 2020 in this case, because these groups enter the labour market sooner. The gain for the supported cohort is smaller than if young children were supported. Increases in the average German gross income and pension value are much more moderate. This is caused by the smaller learning multiplier for adolescents relative to young children (see Figure 1). On the other hand, benefits would already come out by 2020 if adolescents were supported instead of young children, because those age-groups enter the labour market shortly after, providing more human capital than without the policy. Since this effect is only marginal (e.g. the average pension will be just $7 €$ than without the policy) supporting young children is generally superior.

Both policies lead to positive feedback loops. In 2050, for instance, the age-groups that were supported in 2011 will have a higher amount of human capital and income, thus paying more taxes. The tax payment, on the other hand is again used to support 
the children in the future. This effect also explains why the benefits of supporting the youngest continue to increase until 2080 compared to the benefits if adolescents are supported.

In a variant of this model an exogenous technical progress of 1 percent p.a. is assumed (compare Buchheim 1997). In this case average income and pensions will not decrease as a result of demographic change. In combination with technological progress policy benefits are greater, e.g. the policy makes the pension value rise until 2080 by about $7 €$ compared to approximately $2 €$ when there is no technological progress (14\% compared to $8.4 \%$ in relative terms, respectively). The effects on income are similar to the effect on pensions. Thus, human capital and technological progress complement each other. The return on an investment of one Euro today is greater if the resulting human capital increase is enhanced by a better technology. Figure 9 shows that the effects of investments between 12 and 17 years are similar, but significantly smaller, confirming the case of no technological progress.

To sum up, investments in education and human capital are able to mitigate the effects of aging during the demographic transition, which is in line with Vogel et al. (2013).

\subsection{Lifetime income effects for different cohorts}

This section investigates which cohorts will profit or lose as a result of tax-financed educational investments. Individuals will have to pay higher taxes during their working life and they may receive higher pensions in old age. Time preferences are assumed to be the same for all individuals. Without technological progress, taxes always surpass the benefit for the population of workers in 2010, who have to pay the tax.

If technological progress is one percent, age groups born before 1945 will barely be affected by the policy, because they will neither pay additional taxes nor experience an increase in their pensions as pensions only rise with a delay of several decades. For the cohorts born between 1948 and 1976 taxes are higher than benefits. These cohorts will have to pay high taxes since they are at or near their humn capital peak. The higher pensions do not compensate these costs mainly because of the lag of several decades between educational investments and returns. For the cohorts of workers born between 1955 and 1965 the loss is the highest. Workers born after 1976 will experience an increase in their life time income. They are still young enough to experience significantly higher pensions in old age as a result of additional educational investments.

To sum up, if technological progress is sufficiently large, policy impacts are positive, but not for all cohorts. For older cohorts born between 1948 and 1976 the net benefit 
is negative, while for workers born after 1976 net benefits will be positive. Compared to additional educational investment during childhood investments during adolescence (12 to 17 years), i.e. higher secondary education, will produce a loss for all cohorts born before 1990. The German pay-as-you-go pension system requires a long planning horizon. The longer the horizon, the more additional educational investments during childhood will earn a positive return. Such a long planning perspective is difficult to realise in a democracy (see Kemnitz und von Weizsäcker 2003). For instance the cohort born between 1994 and 2003 will profit more from educational investments during adolescents compared to childhood. Thus, they presumably vote for this alternative 2010 .

Figure 10 illustrates the discounted lifetime income for the cohorts born between 1994 and 2043. If additional educational investmentes takes place in secondary school age, the cohort born in 1994 is the first to profit from the investments. If additional educational investmentes takes place in childhood, the cohort born in 2006 is the first to profit from the investments. The net income gain is significantly higher compared to the investment into in secondary school age.

\section{Conclusions}

The paper studies the power of educational investments in relation to transfers for fostering lifetime income and for reducing income inequality in Germany. We contribute to the discussion of the long-run development of the German public pension system in times of demographic transition in a novel way. Costs and benefits of public transfer payments are examined that directly reduce income inequality at older age (called remedial policies) and compared with investments into education, beginning already at preschool age (called preventative policies). Furthermore, the paper studies the power of age-dependent educational investments for the development of lifetime income and inequality for cohorts born 1940 to 2044 over the period from 2010 to 2080. The analysis is based on a model of age-dependent human capital accumulation, featuring dynamic complementarities in skill formation over the life cycle.

According to the findings educational investments are more effective in reducing income inequality than transfers in one generation until the age of 17 years. The relationship reverses after the age of 17. In case of remedial pension transfers in old age, the "rich" pensioner has to spend $100,000 €$ at the age of 65 years in order to increase the income of the "poor" pensioner so that the income inequality ratio is reduced moderately from 3.3 to 3.1 in Germany. To achieve the same reduction in inequality, the value of additional educational investments in preschool assessed at the age of 65 years is only $10,398 €$, demonstrating the power of the childhood skill multiplier.

In the next decades the German population will mature further since life expectation increase and fertily rates are low. Presumably, the old age dependency ratio will in- 
crease from 30 to 50 percent, and the growth in pensions will be slow or even negative. Tax-financed educational investments starting in 2011 could be helpful to moderate the economic consequences of demographic transition. The findings suggest that benefits will be positive on average, but not for all cohorts, mainly because of the lag between investment and increased human capital. Cohorts born after 1976 will gain. The longer the planning horizon, the more positive is the impact of educational investments on pensions in the German pension system. Investments into the youngest are the most productive. Additional educational investments into secondary education will presumably not raise lifetime income enough to compensate its costs.

Our study provides some novel preliminary evidence for lifetime incomes during demographic transition with a focus on educational investments and transfers. More research is needed to understand the differential role of alternative policies that aim at fostering lifetime income and reducing income inequality, such as pensions and labour market policies. 


\section{References}

Armor, D. J.. 2003. Maximizing Intelligence. New Brunswick: Transaction Publishers.

Atkinson, A. B. (1970), On the Measurement of Inequality, Journal of Economic Theory, 2 (3), 244-263.

Beckett C., B. Maughan, M. Rutter, J. Castle, E. Colvert, C. Groothues, J. Kreppner, S. Stevens, T. O'Connor and E. J. S. Sonuga-Barke. 2006. Do the Effects of Early Severe Deprivation on Cognition Persist Into Early Adolescence? Findings from the English and Romanian Adoptees Study. Child Development 77 (3), 696-711.

Blomeyer, D., K. Coneus, M. Laucht and F. Pfeiffer (2013): Early life adversity and children's competence development: Evidence from the Mannheim Study of Children at Risk, Journal of Economics and Statistics (in print).

Blomeyer, D., K. Coneus, M. Laucht and F. Pfeiffer (2009): Initial Risk Matrix, Home Resources, Ability Development and Children's Achievement, Journal of the European Economic Association 7(2-3), 638-648.

Borghans, L., A. L. Duckworth, J. J. Heckman and B. ter Weel. 2008. The Economics and Psychology of Cognitive and Non-Cognitive Traits, Journal of Human Resources, 43(4), 972-1059.

Börsch-Supan, A., A. Reil-Held and D. Schunk. 2008. Saving incentives, old-age provision and displacement effects: Evidence from the recent German pension reform, Journal of Pension Economics and Finance, 7, 03 295-319

Börsch-Supan, A. and A. Ludwig. 2009. Living Standards in an Aging Germany: The Benefits of Reforms and the Costs of Resistance. Journal of Economics and Statistics, 229, 2+3 163-179.

Buchheim, C.. 1997. Einführung in die Wirtschaftsgeschichte. CH Beck, München.

Commission of the German government for achieving financial sustainability for the social security systems. 2003. Szenario der Kommission zur demographischen und ökonomischen Entwicklung bis zum Jahr 2040. Bundesministerium für Gesundheit und Soziale Sicherung. Berlin.

Coneus, K., M. Laucht and K. Reuß (2012): The Role of Parental Investments for cognitive and noncognitive skill formation - Evidence for the first 11 years of life, Economics and Human Biology 10, 189-209.

Cunha, F. and J. J. Heckman. 2007. The Technology of Skill Formation. American Economic Review 97(2), 31-47.

Cunha, F. and J. J. Heckman. 2008a. A New Framework for the Analysis of Inequality. Macroeconomic Dynamics, 12, 315-354. 
Cunha, F. and J. J. Heckman. 2008b. Formulating, Identifying and Estimating the Technology of Cognitive and Noncognitive Skill Formation. Journal of Human Resources, 43(4). 738-782.

Cunha, F. and Heckman, J.J., 2009. The economics and psychology of inequality and human development. Journal of the European Economic Association 7(2-3).

Cunha, F., J. J. Heckman, L. Lochner and D. V. Masterov. 2006. Interpreting the Evidence on Life Cycle Skill Formation, in: E.A. Hanushek and F. Welsch (Eds.). Handbook of the Economics of Education. Amsterdam: North-Holland.

Deutsches Institut für Altersvorsorge. 2011. Gesetzliche Rentenversicherung. http://www.dia-vorsorge.de (retrieved 08.07.2011)

Duckworth, A. L. and M. E. P. Seligman. 2005. Self-Discipline outdoes IQ in Predicting Academic Performance. Psychological Science 16(12), 939-944.

Dustmann, C., J. Ludsteck and U. Schoenberg.2009. Revisiting the German Wage Structure. Quarterly Journal of Economics 124 (2). 843- 881.

Federal Statistical Office Germany. 2009a. 12. koordinierte Bevölkerungsvorausberechnung. Statistisches Bundesamt. Wiesbaden.

Federal Statistical Office Germany. 2009b. Bevölkerung und Erwerbstätigkeit: Wanderungen. Statistisches Bundesamt. Wiesbaden.

Federal Statistical Office Germany. 2010a. Statistisches Jahrbuch Deutschland, Statistisches Bundesamt. Wiesbaden.

Federal Statistical Office Germany. 2010b. Statistik der Geburten, Statistisches Bundesamt. Wiesbaden. http://opendatalabs.org/destatis/table_12612-0102.html (retrieved 08.07.2011)

Federal Statistical Office Germany. 2011. Periodensterbetafeln für Deutschland: Allgemeine Sterbetafeln, abgekürzte Sterbetafeln und Sterbetafeln, Statistisches Bundesamt, Wiesbaden.

Gebel, M. and F. Pfeiffer (2010). Educational Expansion and its Heterogeneous Returns for Wage Workers. Schmollers Jahrbuch - Journal of Applied Social Science Studies 130 (1), 19-42.

German Federal Pension Insurance. 2009. Jahresbericht: Die Deutsche Rentenversicherung im Überblick, Berlin.

German Federal Pension Insurance. 2011. Aktuelle Daten 2011. http://www.deutsche-rentenversicherung.de (retrieved 08.07.2010)

Gernandt, J. and F. Pfeiffer. 2007. Rising Wage Inequality in Germany, Journal of Economics and Statistics, 227 (4), 358-380.

Hanushek, E. A., Wössmann, L., 2008. The Role of Cognitive Skills in Economic Development, Journal of Economic Literature 46 (3), 607-668. 
Heckhausen, J. and H. Heckhausen (2006), Motivation und Entwicklung. In J. Heckhausen and H. Heckhausen, Motivation und Handeln. Berlin: Springer Verlag, 393-454.

Heckman, J. J.. 2007. The Economics, Technology and Neuroscience of Human Capability Formation. Proceedings of the National Academy of Sciences 104(3). 13250-5.

Kemnitz, A. and K. von Weizsäcker. 2003. Bildungsreform in der Demokratie. Vierteljahrshefte zur Wirtschaftsforschung 72 (2). 188-204.

Krebs, T.. 2003. Human Capital Risk and Economic Growth. Quarterly Journal of Economics. 118(2), 709-44.

Krüger, D. and F. Kübler. 2002. Intergenerational Risk Sharing via Social Security when Financial Markets are Incomplete. American Economic Review, Papers and Proceedings 92 (2). 407-410.

OECD 2010. Education at a Glance. OECD, Paris.

OECD.stat. 2011. OECD Statistics. http://stats.oecd.org (retrieved 10.07.2011).

Pfeiffer, F. and K. Reuss. 2008a. Age-Dependent Skill Formation and Returns to Education, Labour Economics, 15 (4). 631-646.

Pfeiffer, F. and K. Reuss. 2008b. Intra- und intergenerationale Umverteilungseffekte in der bundesdeutschen Alterssicherung auf Basis humankapitaltheoretischer Überlegungen, Deutsche Rentenversicherung 63 (1), 60-84.

Pfeiffer, F. and K. Reuss. 2011. Human Capital Investment Strategies in Europe. ZEW Discussion Paper 11-033. Mannheim.

Restuccia, D. and C. Urrutia. 2004. Intergenerational Persistence of Earnings: the Role of Early and College Education. American Economic Review 94 (5). 13541378.

Vogel, E., Ludwig, A. and A. Börsch-Supan. 2013. Aging and Pension Reform: Extending the Retirement Age and Human Capital Formation. NBER Working Paper No. w18856. 


\section{Figures and Tables}

Figure 1: Learning multipliers (top) and life cycle skill development (down)
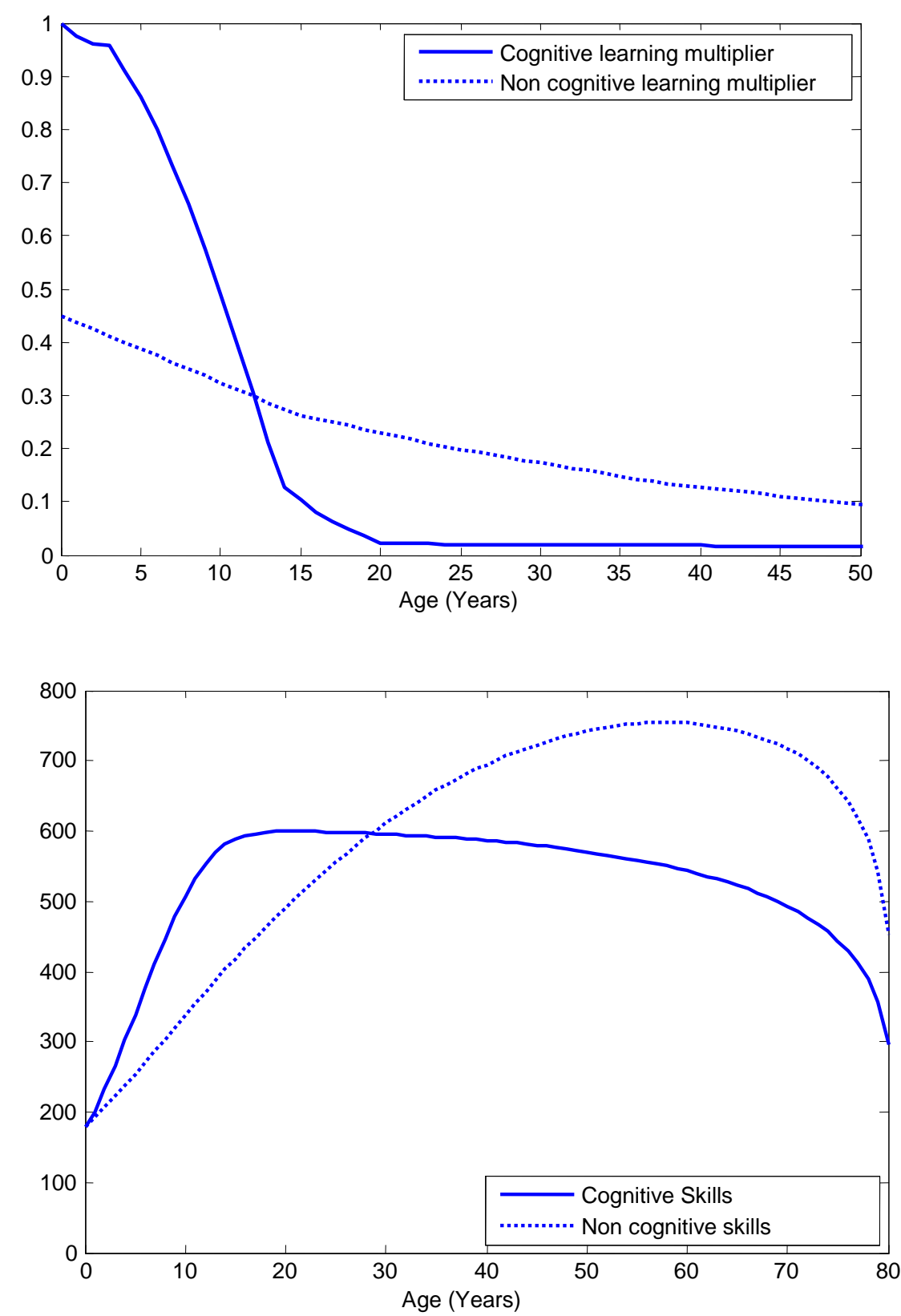
Figure 2: Income stream over the life cycle for high and low skilled, without (top) and with (down) a pension system
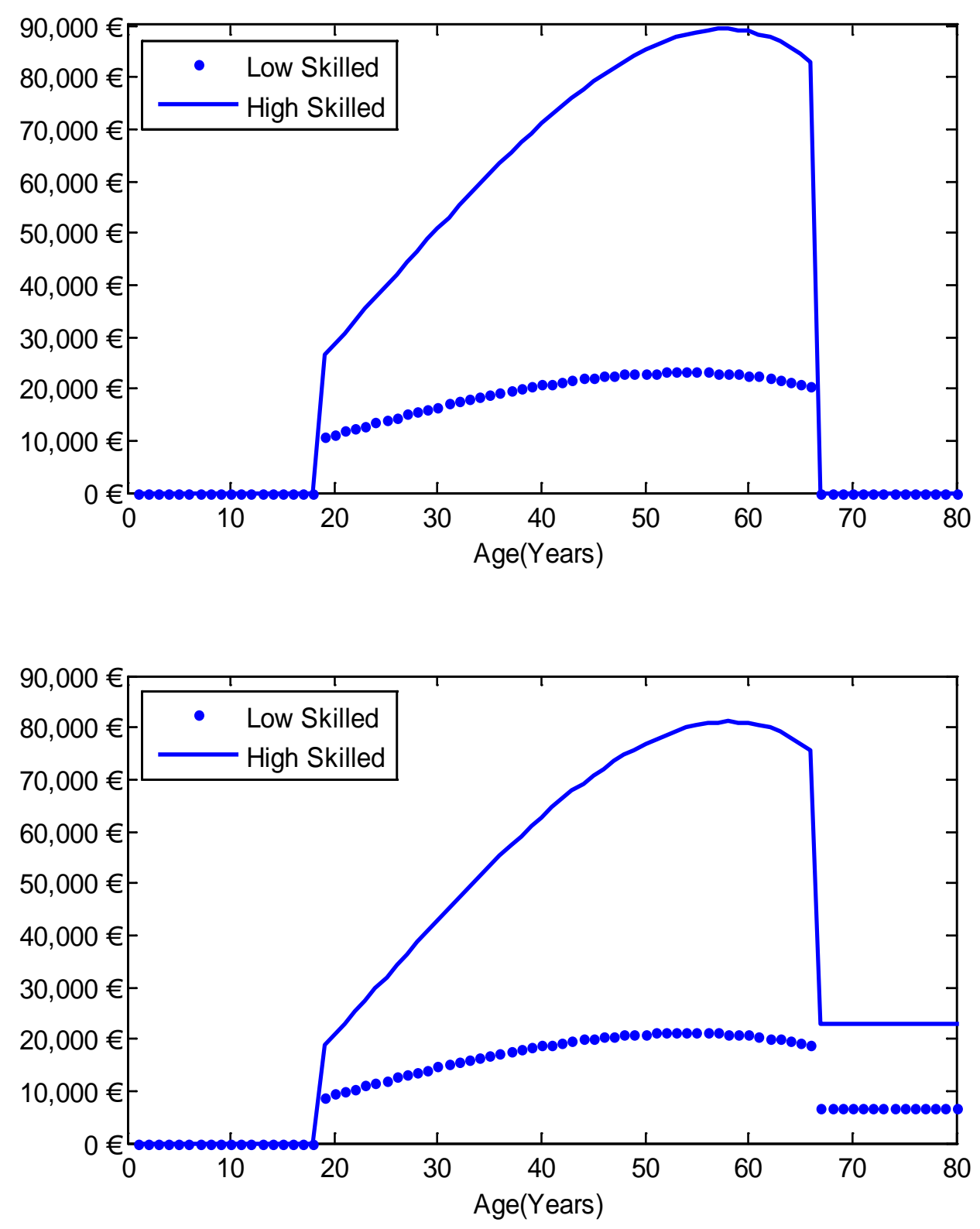
Figure 3: Optimal educational investment during adult life

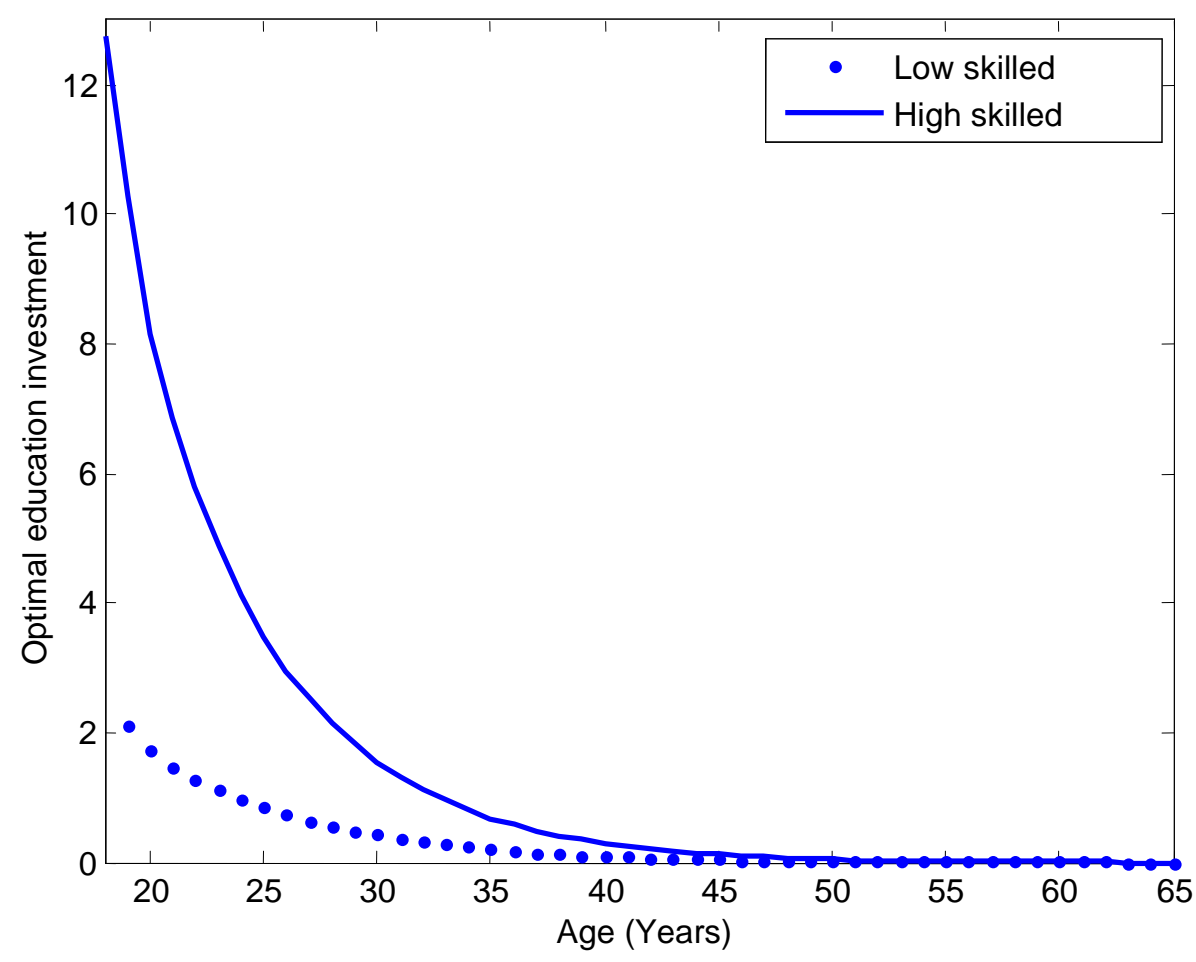


Figure 4: Welfare change for three different redistribution policies and four different values of inequality aversion
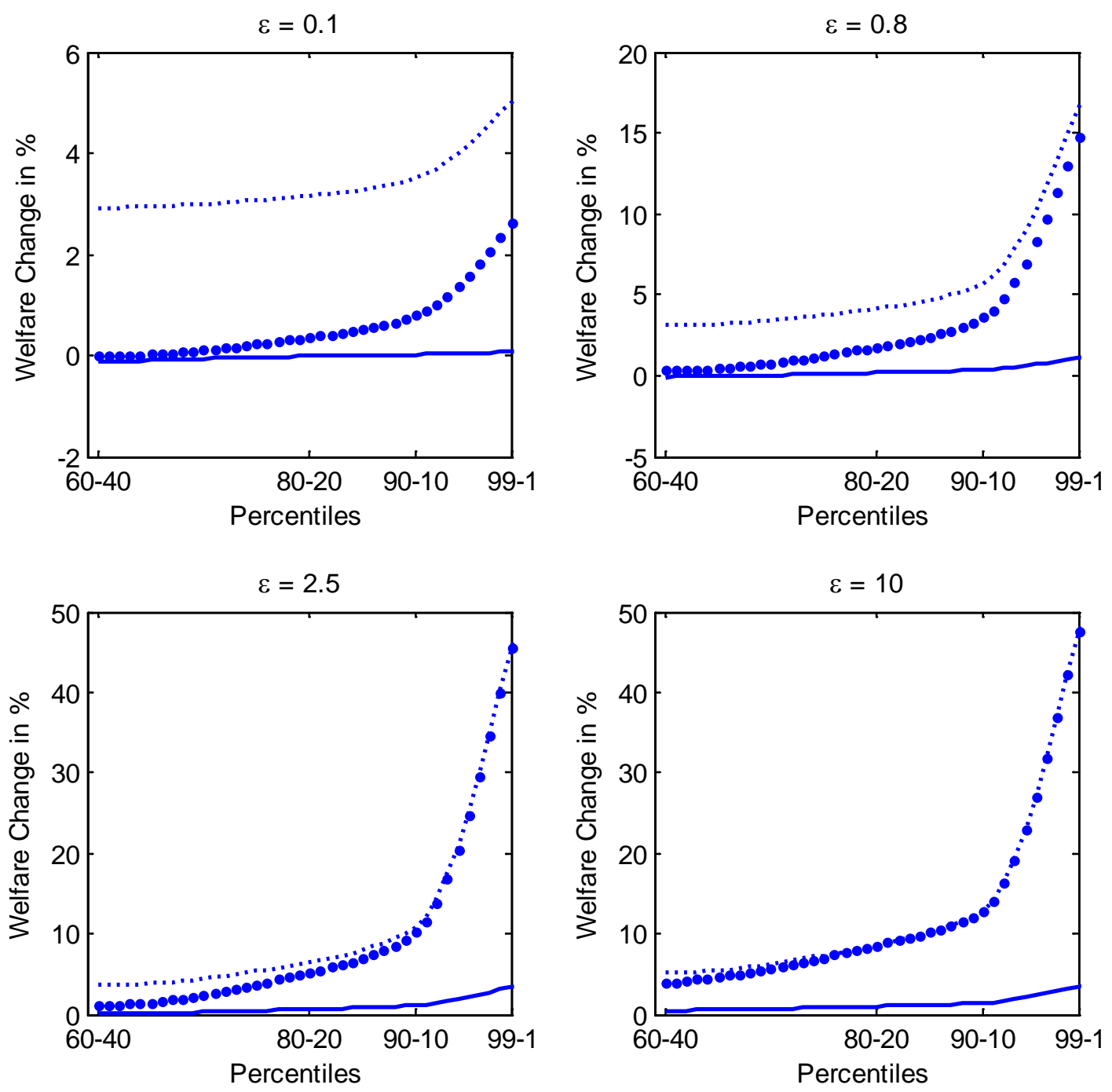

a) Redistribution of pensions

- b) Redistribution of investments in education

c) Pension-financed investment in education 
Figure 5: Age-dependent costs for preventative and premedial policies

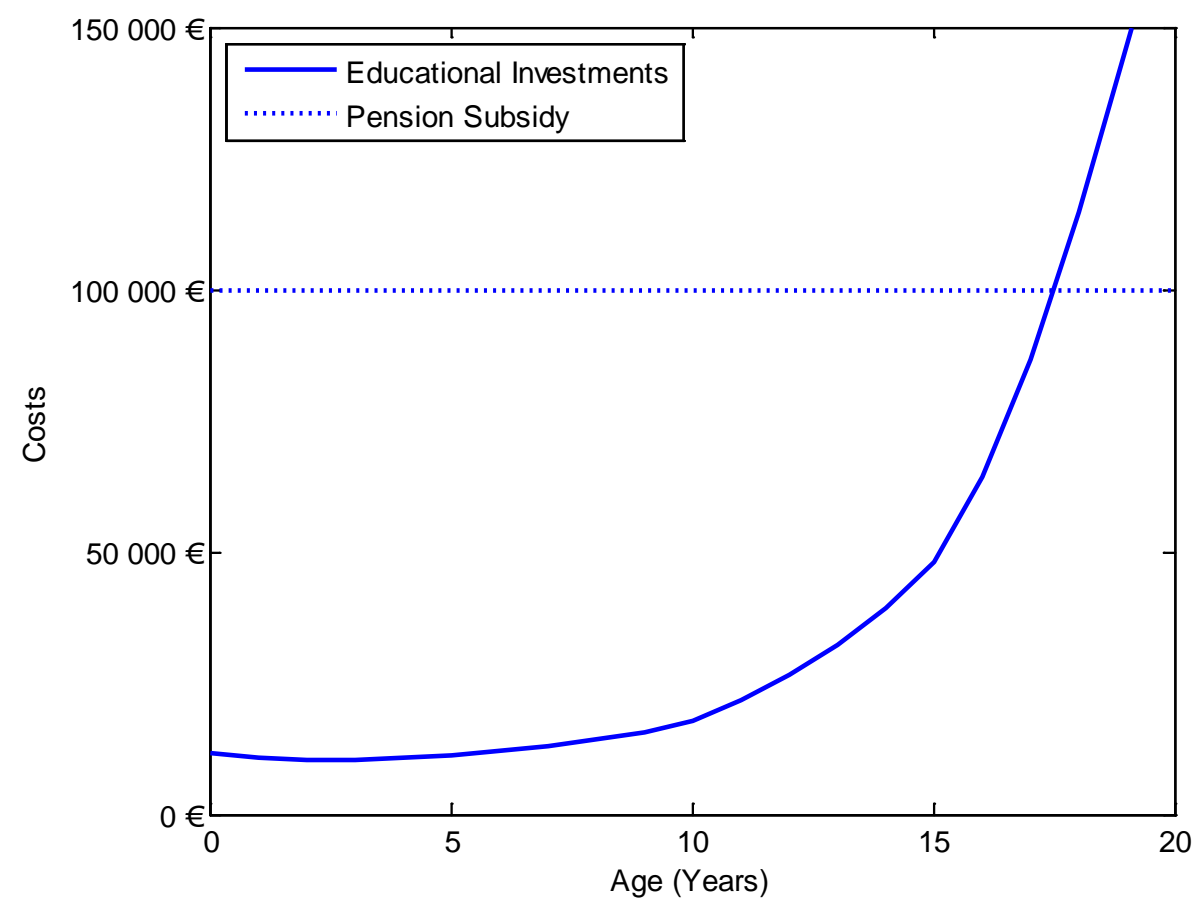


Figure 6: Population development (2010 until 2050)

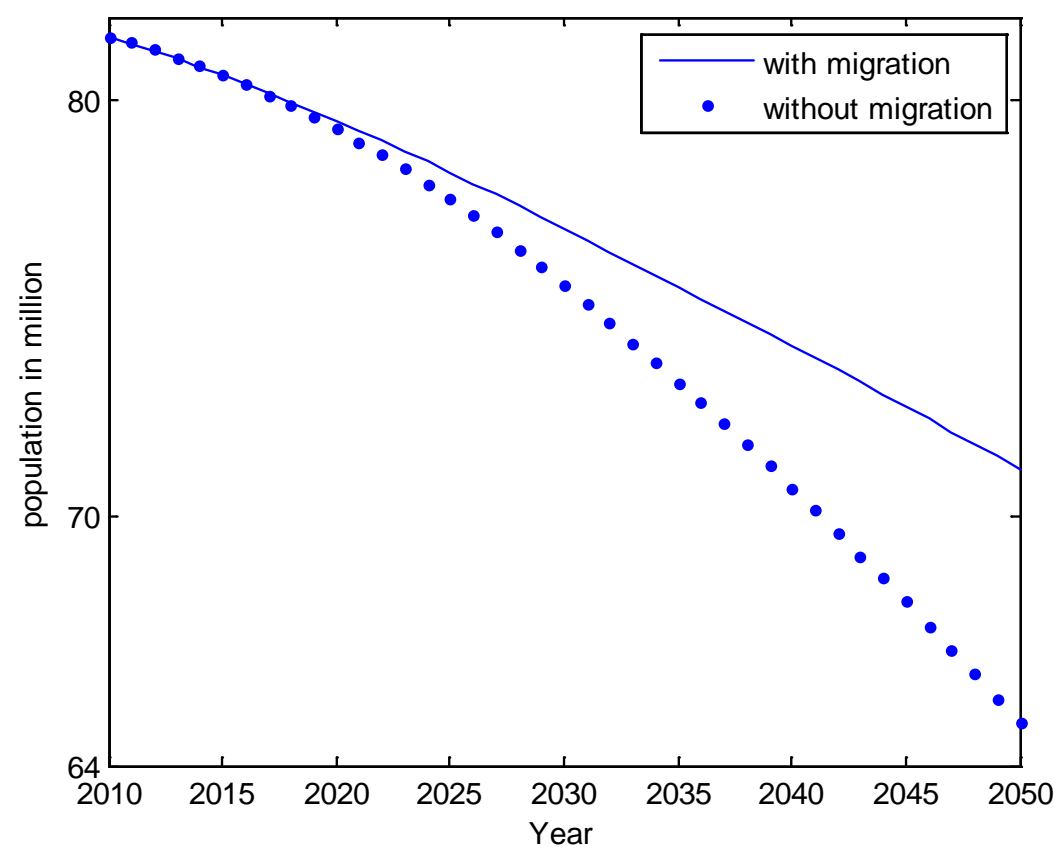

Figure 7: The development of the old-age dependency ratio until 2050

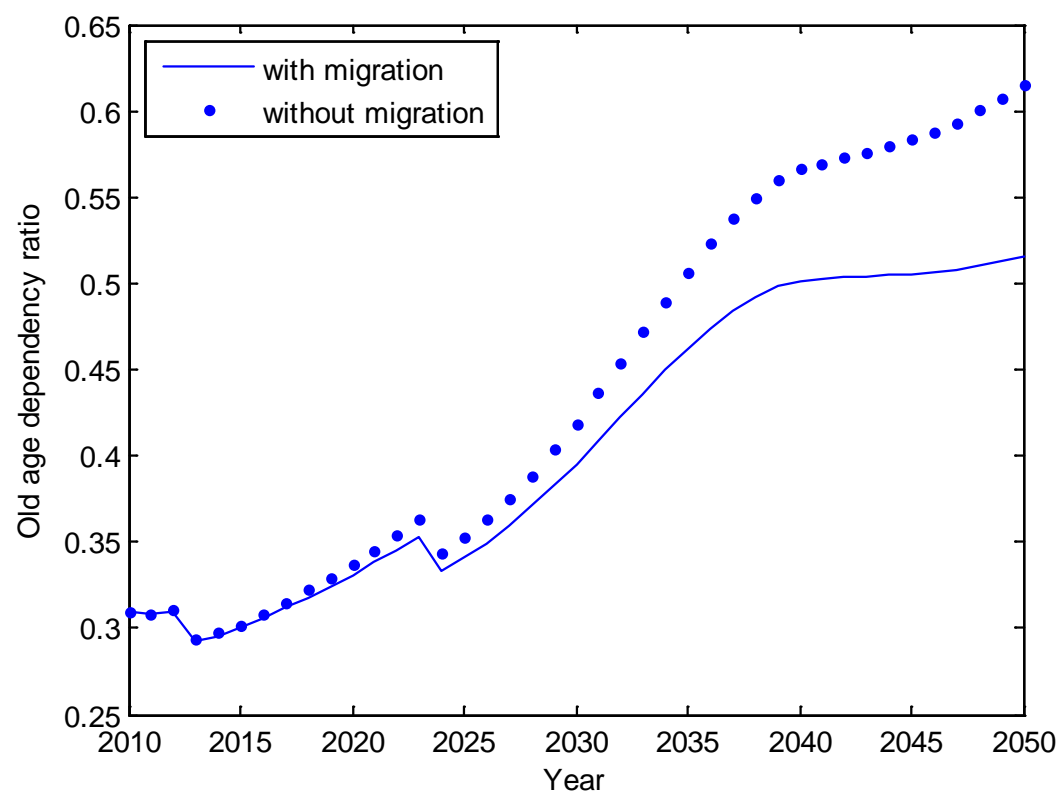


Figure 8: Income over the life cycle, average income per capita, pension value and the contribution rate without and with additional investment in childhood
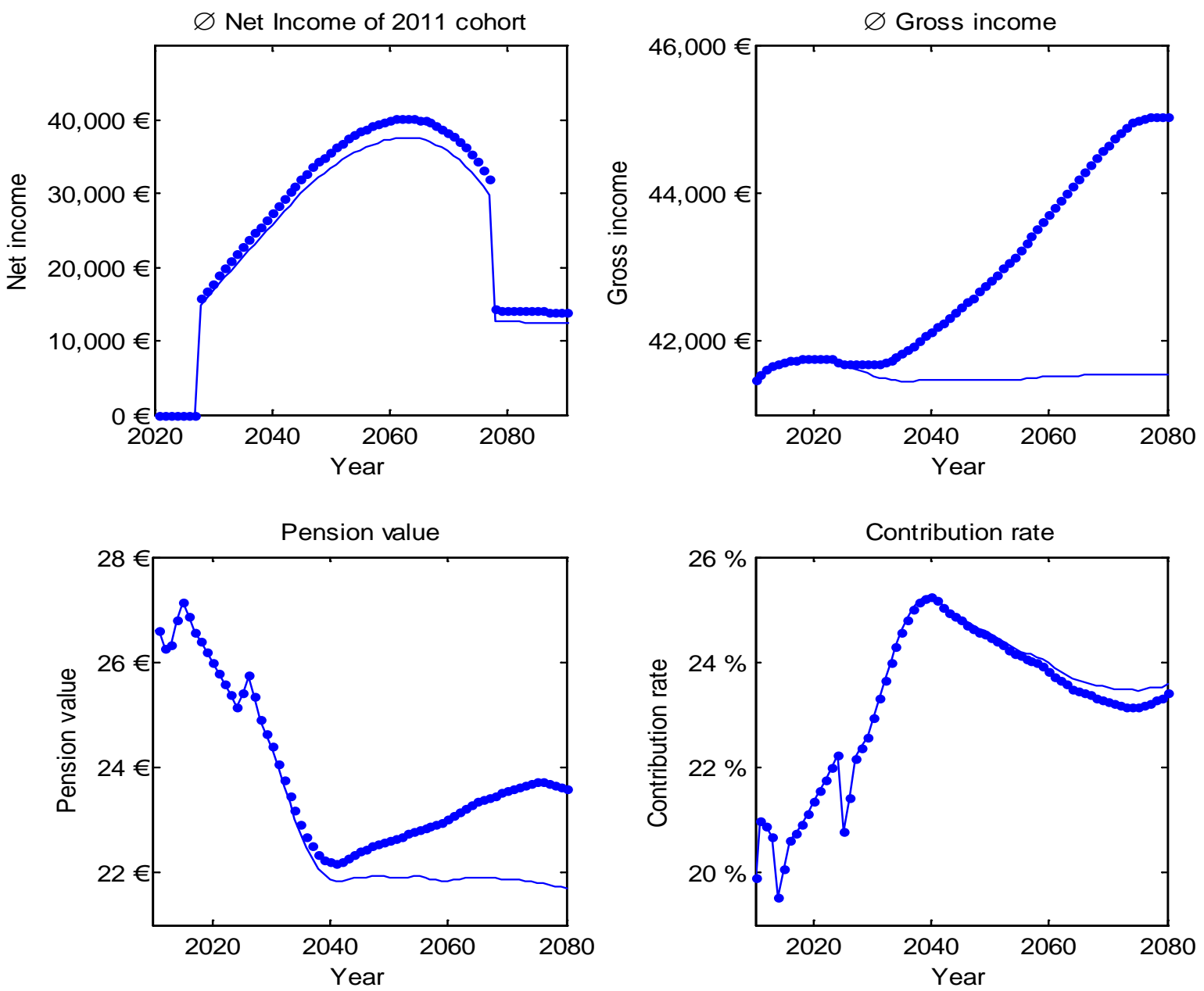

$$
\begin{aligned}
& \text { without policy } \\
& \text { with policy }
\end{aligned}
$$


Figure 9: Income over the life cycle, average income per capita, pension value and the contribution rate without and with additional investment in childhood, and with an exogenous progress of one percent p.a.
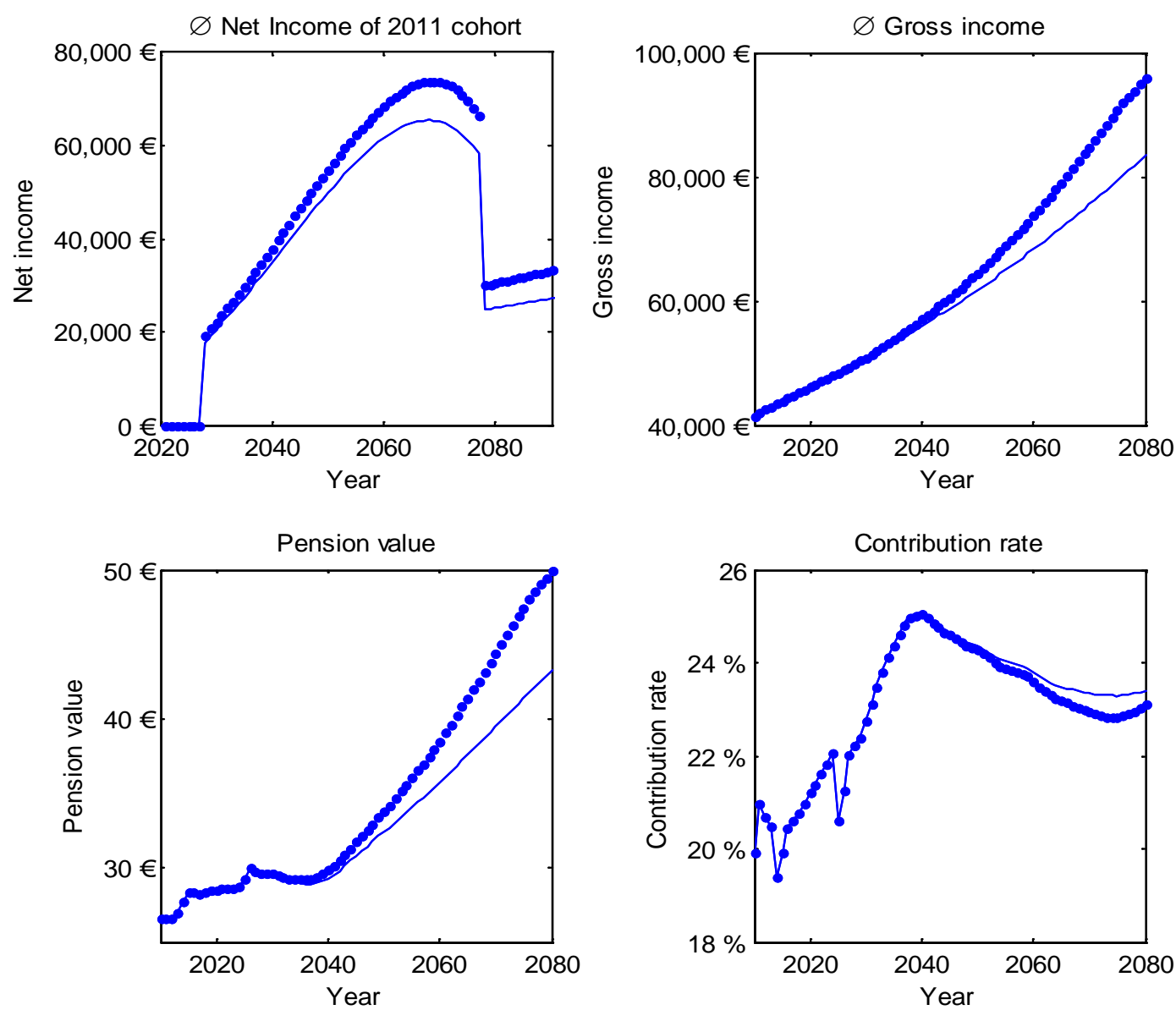

\footnotetext{
without policy

- with policy
} 
Figure 10: Change in discounted lifetime income for cohorts born from 1944 to 1993 by a tax-financed educational investment during childhood and adolescence

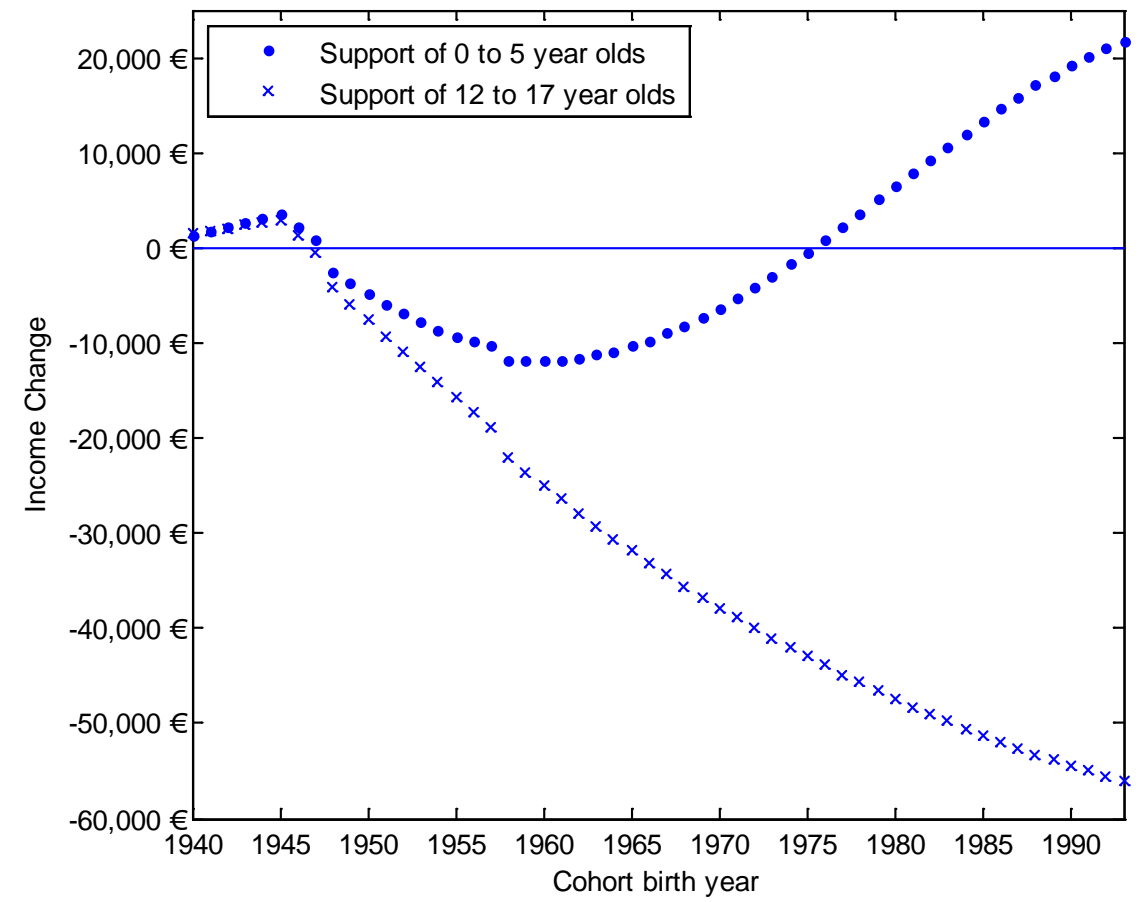


Table 1: Policies to reduce lifetime inequality between high and low skilled

\begin{tabular}{|c|c|c|c|c|c|}
\hline \multicolumn{6}{|c|}{ H: $60^{\text {th }}$ percentile L: $40^{\text {th }}$ percentile } \\
\hline & $\begin{array}{l}\text { investments } \\
\text { in education } \\
\text { during work- } \\
\text { ing life, } \\
\varnothing \text { per annum }\end{array}$ & $\begin{array}{l}\text { Net labour in- } \\
\text { comes } \\
\text { (discounted to } \\
\text { age 65) }\end{array}$ & $\begin{array}{l}\text { Cumulated } \\
\text { pension re- } \\
\text { ceipts } \\
\text { (discounted to } \\
\text { age 65) }\end{array}$ & $\begin{array}{l}\text { Total income } \\
\text { (change) }\end{array}$ & $\begin{array}{l}\text { Ine- } \\
\text { quality } \\
\text { ratio }\end{array}$ \\
\hline Initial situation & $\begin{array}{l}\text { L: } 0.83 \\
H: 1.13 \\
\sum: 1.96\end{array}$ & $\begin{array}{l}\text { L: } 2,466,407 € \\
\text { H: } 3,094,008 €\end{array}$ & $\begin{array}{l}\text { L: } 161,010 € \\
H: 204,268 €\end{array}$ & $5,925,693 €$ & 1.26 \\
\hline $\begin{array}{l}\text { a) Redistribution of } \\
\text { pensions }\end{array}$ & $\begin{array}{l}\mathrm{L}: 0.78 \\
\mathrm{H}: 1.07 \\
\sum: 1.86\end{array}$ & $\begin{array}{l}\text { L: } 2,463,469 € \\
\text { H: 3,090,063 € }\end{array}$ & $\begin{array}{l}\text { L: } 180,277 € \\
\text { H: } 183,418 €\end{array}$ & $\begin{array}{c}5,917,277 € \\
(-0.14 \%)\end{array}$ & 1.24 \\
\hline $\begin{array}{l}\text { b) redistribution of } \\
\text { investments in edu- } \\
\text { cation }\end{array}$ & $\begin{array}{c}\mathrm{L}: 0.9 \\
\mathrm{H}: 1.06 \\
\sum: 1.95\end{array}$ & $\begin{array}{l}\text { L: } 2,612,204 € \\
\text { H: } 2,944,657 €\end{array}$ & $\begin{array}{l}\mathrm{L}: 170,933 € \\
\mathrm{H}: 194,057 €\end{array}$ & $\begin{array}{c}5,921,850 € \\
(-0.06 \%)\end{array}$ & 1.13 \\
\hline $\begin{array}{l}\text { c) pension-financed } \\
\text { investment in edu- } \\
\text { cation }\end{array}$ & $\begin{array}{c}\text { L: } 0.9 \\
\text { H: } 1.13 \\
\sum: 2.03\end{array}$ & $\begin{array}{l}\text { L: } 2,612,188 € \\
\text { H: 3,094,024 € }\end{array}$ & $\begin{array}{l}\text { L: } 170,852 € \\
H: 220,383 €\end{array}$ & $\begin{array}{c}6,097,447 € \\
(+2.90 \%)\end{array}$ & 1.19 \\
\hline \multicolumn{6}{|c|}{ H: $80^{\text {th }}$ percentile L: $20^{\text {th }}$ percentile } \\
\hline & $\begin{array}{l}\text { L: } 0.53 \\
H: 1.52 \\
\sum: 2.05\end{array}$ & $\begin{array}{l}\text { L: } 1,804,949 € \\
\text { H: } 3,833,999 €\end{array}$ & $\begin{array}{l}\text { L: } 115,825 € \\
H: 255,398 €\end{array}$ & $6,010,171 €$ & 2.13 \\
\hline $\begin{array}{l}\text { a) Redistribution of } \\
\text { pensions }\end{array}$ & $\begin{array}{l}\mathrm{L}: 0.53 \\
\mathrm{H}: 1.5 \\
\sum: 2.03\end{array}$ & $\begin{array}{l}\text { L: } 1,804,475 € \\
\text { H: } 3,832,592 €\end{array}$ & $\begin{array}{l}\text { L: } 135,647 € \\
H: 235,130 €\end{array}$ & $\begin{array}{c}6,007,844 € \\
(-0.04 \%)\end{array}$ & 2.10 \\
\hline $\begin{array}{l}\text { b) redistribution of } \\
\text { investments in edu- } \\
\text { cation }\end{array}$ & $\begin{array}{c}\text { L: } 0.6 \\
\text { H: } 1.44 \\
\sum: 2.04\end{array}$ & $\begin{array}{l}\text { L: } 1,960,368 € \\
\text { H: } 3,688,609 €\end{array}$ & $\begin{array}{l}\mathrm{L}: 126,247 € \\
\mathrm{H}: 245,445 €\end{array}$ & $\begin{array}{c}6,020,669 € \\
(+0.17 \%)\end{array}$ & 1.89 \\
\hline $\begin{array}{l}\text { c) pension-financed } \\
\text { investment in edu- } \\
\text { cation }\end{array}$ & $\begin{array}{c}\text { L: } 0.6 \\
\text { H: } 1.52 \\
\sum: 2.12\end{array}$ & $\begin{array}{l}\text { L: } 1,960,349 € \\
\text { H: } 3,834,027 €\end{array}$ & $\begin{array}{l}\text { L: } 126,176 € \\
\text { H: } 271,563 €\end{array}$ & $\begin{array}{l}6,192,114 € \\
(+3.027 \%)\end{array}$ & 1.97 \\
\hline \multicolumn{6}{|c|}{ H: $90^{\text {th }}$ percentile L: $10^{\text {th }}$ percentile } \\
\hline Initial situation & $\begin{array}{l}\text { L: } 0.35 \\
H: 1.84 \\
\sum: 2.18\end{array}$ & $\begin{array}{l}\text { L: } 1,330,668 € \\
\text { H: } 4,401,861 €\end{array}$ & $\begin{array}{c}\text { L: } 83,926 € \\
H: 294,553 €\end{array}$ & $6,111,008 €$ & 3.32 \\
\hline $\begin{array}{l}\text { a) Redistribution of } \\
\text { pensions }\end{array}$ & $\begin{array}{l}\mathrm{L}: 0.35 \\
\mathrm{H}: 1.82 \\
\sum: 2.17\end{array}$ & $\begin{array}{l}\text { L: } 1,330,578 € \\
\text { H: } 4,400,907 €\end{array}$ & $\begin{array}{l}\mathrm{L}: 103,859 € \\
\mathrm{H}: 274,371 €\end{array}$ & $\begin{array}{l}6,109,716 € \\
(-0.021 \%)\end{array}$ & 3.26 \\
\hline $\begin{array}{l}\text { b) redistribution of } \\
\text { investments in edu- } \\
\text { cation }\end{array}$ & $\begin{array}{l}\mathrm{L}: 0.41 \\
\mathrm{H}: 1.75 \\
\sum: 2.17\end{array}$ & $\begin{array}{l}\text { L: } 1,501,597 € \\
\text { H: } 4,257,619 €\end{array}$ & $\begin{array}{c}\mathrm{L}: 95,196 € \\
\mathrm{H}: 284,732 €\end{array}$ & $\begin{array}{l}6,139,145 € \\
(+0.482 \%)\end{array}$ & 2.85 \\
\hline $\begin{array}{l}\text { c) pension-financed } \\
\text { investment in edu- } \\
\text { cation }\end{array}$ & $\begin{array}{l}L: 0.41 \\
H: 1.84 \\
\sum: 2.25\end{array}$ & $\begin{array}{l}\text { L: } 1,501,572 € \\
\text { H: } 4,401,906 €\end{array}$ & $\begin{array}{c}\text { L: } 95,139 € \\
\text { H: } 310,804 €\end{array}$ & $\begin{array}{l}6,309,421 € \\
(+3.269 \%)\end{array}$ & 2.95 \\
\hline
\end{tabular}


Table 1: Policies to reduce lifetime inequality between high and low skilled (cont.)

\begin{tabular}{|c|c|c|c|c|c|}
\hline \multicolumn{6}{|c|}{ H: $99^{\text {th }}$ percentile L: $1^{\text {st }}$ percentile } \\
\hline Initial situation & $\begin{array}{l}\text { L: } 0.09 \\
\text { H: } 2.78 \\
\sum: 2.87\end{array}$ & $\begin{array}{c}\text { L: } 539,196 € \\
H: 5,970,516 €\end{array}$ & $\begin{array}{c}\mathrm{L}: 32,258 € \\
\mathrm{H}: 402,134 €\end{array}$ & $6,944,105 €$ & 11.15 \\
\hline $\begin{array}{l}\text { a) Redistribution of } \\
\text { pensions }\end{array}$ & $\begin{array}{l}\text { L: } 0.09 \\
\text { H: } 2.77 \\
\sum: 2.87 \\
\end{array}$ & $\begin{array}{c}\text { L: } 539,337 € \\
\text { H: 5,970,006 € }\end{array}$ & $\begin{array}{c}\text { L: } 52,243 € \\
H: 382,063 €\end{array}$ & $\begin{array}{c}6,943,649 € \\
(+0.00 \%)\end{array}$ & 10.74 \\
\hline $\begin{array}{l}\text { b) redistribution of } \\
\text { investments in edu- } \\
\text { cation }\end{array}$ & $\begin{array}{l}\text { L: } 0.16 \\
\text { H: } 2.69 \\
\sum: 2.85\end{array}$ & $\begin{array}{c}\text { L: } 795,386 € \\
\text { H: } 5,825,731 €\end{array}$ & $\begin{array}{c}\mathrm{L}: 48,314 € \\
\mathrm{H}: 392,712 €\end{array}$ & $\begin{array}{c}7,062,142 € \\
(+1.70 \%)\end{array}$ & 7.37 \\
\hline $\begin{array}{l}\text { c) pension-financed } \\
\text { investment in edu- } \\
\text { cation }\end{array}$ & $\begin{array}{l}\text { L: } 0.16 \\
\text { H: } 2.78 \\
\sum: 2.94\end{array}$ & $\begin{array}{c}\text { L: } 795,358 € \\
\text { H: 5,970,606 € }\end{array}$ & $\begin{array}{c}\text { L: } 48,288 € \\
\text { H: } 418,900 €\end{array}$ & $\begin{array}{c}4685766 € \\
(+4.16 \%)\end{array}$ & 7.57 \\
\hline
\end{tabular}

